\title{
THE EFFECT OF PEPTONE ON THE TOXIGENIC PROPERTY OF B. DIPHTHERIAE NO. 8
}

Harriet LesLie Wilcox

From the Research Laboratories, Department of Health, New York City

It is known to all laboratory workers who are familiar with the production of diphtheria toxin that the strain of B. diphtheriae used in obtaining a potent toxin is called No. 8. This strain was isolated by Dr. Williams in the summer of 1895 and so stable has been its toxigenic property that it is used, not only in the serum laboratories of the United States but in those of England and Europe as well.

The idea that different cultures of this strain should vary in their toxic productions was not entertained up to about 1916. However, from time to time, requests for new transplants of No. 8 had been received at this laboratory from other workers who said that their cultures had lost the ability to produce a potent toxin. Previous to 1914, our strain was still producing a potent toxin, though with some irregularities in strength.

More recently and coincident with the reports from other laboratories, the potency of the toxin produced at the Bureau of Laboratories has shown a marked decline. The average toxicity of the years 1914, 1915 and 1916 was $1: 200$ (or less) as compared with an average potency of 1:350-1:400 for the years 1911, 1912 and 1913 .

In the summer of 1916 I was privileged to work a few weeks at the Pasteur Institute in Paris and to observe the preparation and inoculation of the diphtheria toxin broth. This procedure consisted of seeding Martin peptone broth ${ }^{1}$ in Fernbach flasks with fairly large amounts of broth culture of No. 8. This culture had been taken to the Pasteur Institute in 1896 by Dr. Williams. The ustual routine for the preparation of diphtheria strain was as follows:

The stock culture was kept on coagulated ox-serum while the other culture was cultivated entirely on Martin peptone broth and was transferred 3 times weekly. The culture on serum was subcultured every 4 weeks and was not used for toxin production unless the broth culture became contaminated; in such case a fresh culture in Martin peptone broth was made from the serum ct1lture. How often recourse to this culture was made, I do not know, but from the careful technic employed one would say, rarely, if ever.

Received for publication Jan. 27, 1922.

1 Ann. de 1'Institut Pasteur, 1897, 12, p. 26. 
On my return several experimental preparations of diphtheria toxin were made. The method of the Pasteur Institute was used as well as their culture of No. 8 which had been brough back to New York. The results were so superior to those obtained by employing Witte peptone broth and our own culture of No. 8 that in January, 1917, Martin peptone broth inoculated with the Pasteur culture of B. diphtheriae No. 8 was adopted as our method of toxin production. Since we were following as closely as possible the Pasteur method, we used the same procedure for the propagation of the culture of $B$. diphtheriae.

Comparative tests of our culture of No. 8 with that of the Pasteur No. 8 were made at Dr. Williams' request. The first two or three tests showed stuch marked difference in favor of Pasteur No. 8 that we decided to discover whether, after a cultivation of several months or longer on Martin peptone broth, our. No. 8 culture would produce as high a toxin in Martin peptone broth as the Pasteur No. 8.

To differentiate between these two cultures of the same strain of No. 8 we have called the culture which has been propagated exclusively at the Bureau of Laboratories, Research No. 8, whereas the culture obtained from Pasteur Institute is designated as Pasteur No. 8. These two cultures were inoculated in Martin peptone broth Dec. 28, 1916, and transferred three times weekly in this medium.

At about the same time these cultures were inoculated similarly into Witte peptone broth, Research No. 8 being planted Dec. 23, 1916, and Pasteur No. 8 Dec. 28, 1916, and were transferred three times weekly.

In the summer of 1919 a second culture of No. 8 was obtained from the Pasteur Institute and this was planted Aug. 19, 1919, in Martin peptone broth, Berna peptone broth and Witte peptone broth; it was designated as Pasteur 2 No. 8.

The records of these cultures, that is, the date each was planted in a different medium, the number of transfers weekly, together with the date and result of the planting to determine purity, were kept on separate cards.

In order to obviate any possibility of the substitution of one medium for another while making the subcultures, the following procedure was adopted:

The cultures Research No. 8, Pasteur No. 8 , and Pasteur 2 No. 8 in the Martin peptone broth were kept in a different containcr than the same cultures in the other peptone broths. At the time of transferring only one container with its respective broth tubes was on the work table, thus avoiding any possibility 
of a Witte peptone broth tube being substituted for a Martin peptone broth tube and vice versa.

The dilutions of the filtered cultures for the animal inoculation were made in $0.8 \% \mathrm{NaCl}$. In the tables in which the toxicity is given as being below $1: 100$ or $1: 200$, etc., it indicates that those were the dilutions inoculated and that they did not kill the test animals, or if they did so, not within the time limits. When a toxin is stated to be of a given strength it means that the given dilution killed a $250 \mathrm{gm}$. guinea-pig within the 4 days with the classical toxic symptoms. Occasionally it was not possible to obtain pigs weighing 250 gm., but in those tests made with heavier pigs, the surplus weight was always discounted in estimating the toxicity. No guinea-pigs weighing below $230 \mathrm{gm}$. were inoculated.

\section{MARTIN PEPTONE BROTH}

The comparative tests of Research No. 8 and Pasteur No. 8 in Martin peptone broth are given in table 1 . It is to be recalled that the cultures were subjected to cultivation in this broth, were transferred three times weekly and were then cultivated under identical conditions. To give the reader the approximate number of generations before the different tests were made, the date of starting the cultures in the different broths is given in the tables.

TABLE 1.

Toxicities Produced in Maktin pertone Broth ry Three Different Cultures of B. Diphtheriae No. 8 After Cultivation in the Same Broth; Transfers Made Three Times a Week

\begin{tabular}{|c|c|c|c|}
\hline Date of 'lest & $\begin{array}{c}\text { Research No. } 8 \\
\text { Cultivation Begun } \\
\text { Dee. } 28,1916\end{array}$ & $\begin{array}{c}\text { Pasteur No. } 8 \\
\text { Cultivation Begun } \\
\text { Dec. } 28,1916\end{array}$ & $\begin{array}{c}\text { Pasteur 2 No. } 8 \\
\text { Cultivation Begun } \\
\text { Aug. } 19,1919\end{array}$ \\
\hline 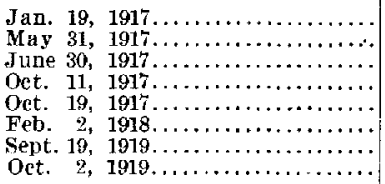 & $\begin{array}{r}1: 100 \\
1: 300 \\
\text { Below } 1: 200 \\
\text { Below } 1: 100 \\
1: 150 \\
1: 100 \\
1: 200 \\
\text { Below } 1: 100\end{array}$ & $\begin{array}{r}1: 400 \\
1: 400 \\
1: 500 \\
1: 300 \\
1: 800 \\
1: 200 \\
1: 600 \\
\text { Below } 1: 200\end{array}$ & $\begin{array}{c}\text { Not tested } \\
\text { Not tested } \\
\text { Not tested } \\
\text { Not tested } \\
\text { Not tested } \\
\text { Not tested } \\
\text { I:G00 } \\
\text { Below } 1: 200\end{array}$ \\
\hline
\end{tabular}

It will be seen that in one test only Research No. 8 approximated Pasteur No. 8 in its toxic production. In the experiment dated May 31, 1917, Research No. 8 gave a toxicity of $1: 300$ as compared with a toxin of $1: 400$ produced by Pasteur No. 8 . The greatest difference in their toxigenic powers was shown in the test dated Oct. 19,1917, when the M L D of Research No. 8 was $1: 150$ in contrast to a potency of $1: 800$ produced by Pasteur No. 8. Subsequent comparative tests showed a diminution in the toxigenic production by both cultures in Martin peptone broth. 
The first test comparing the 3 cultures, Research No. 8, Pasteur No. 8 and Pasteur 2 No. 8, was made Sept. 19, 1919. The results showed that the two Pasteur cultures gave a toxicity of 1:600 whereas the Research No. 8 gave a low M L D of $1: 200$. The last comparative test in Martin peptone broth was made in October, 19.19, but the toxicities in this test were so low that only negative results were obtained.

\section{WITTE PEPTONE BROTH}

The number of tests made using Witte peptone broth was limited, due to the scarcity of the peptone. The broth used in these tests was made according to the formula recommended by Theobald Smith ${ }^{2}$ for obtaining a potent toxin. As in the test made with Martin peptone, the 3 cultures were transferred in the Witte broth 3 times weekly. The period of cultivation may be judged from the dates in table 2 in which the results are given.

TABLE 2

Toxicities Produced in Witte peptone Broth ox Three Different Cultures of B. Diphtheriae No, 8 After Cultivation in the Same Broth; Transfers ThRE TIMES A WeEk

\begin{tabular}{|c|c|c|c|}
\hline Dute of Test & $\begin{array}{c}\text { Resenrch No. } 8^{*} \\
\text { Cultivation Begun } \\
\text { Dec. } 23,1916\end{array}$ & $\begin{array}{c}\text { Pasteur No. } 8 \\
\text { Cultivation Begun } \\
\text { Dec. } 28,1916\end{array}$ & $\begin{array}{l}\text { Pasteur 2 No. } 8 \\
\text { Cultivation Begun } \\
\text { Aug. } 19,1919\end{array}$ \\
\hline 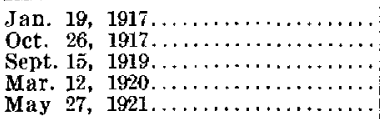 & $\begin{array}{r}\text { Below 1:100 } \\
1: 150 \\
1: 100 \\
\text { Below } 1: 100 \\
\text { Below } 1: 100\end{array}$ & $\begin{array}{r}1: 400 \\
1: 700 \\
1: 400 \\
\text { Below } 1: 100 \\
\text { Below } 1: 200\end{array}$ & $\begin{array}{l}\text { Not tested } \\
\text { Not tested } \\
1: 250 \\
\text { Not tested } \\
\quad 1: 450\end{array}$ \\
\hline
\end{tabular}

* This culture had been carried on in Witte broth since 1895 and transferred every other day as the routine procedure.

It will be noticed that despite the fact that Research No. 8 had been cultivated in a medium containing Witte peptone practically ever since its isolation in 1895, its toxigenic property was much less in the first three tests than that of Pasteur No. 8. The test made May 27, 1921, was a great surprise for it was the first time that Pasteur 2 No. 8 had given a higher potency than Pasteur No. 8. Whether this difference would have been demonstrable in the March 12,1920, test it is impossible to say, but it is evident that the toxigenic property of Pasteur No. 8 in Witte broth had deteriorated. Further reference to this will be made in the following pages.

a Jour. Fxper. Med., 1899, 4, 13. 373. 
BERNA PEPTONE BROTH

It was stated in the foregoing that Martin peptone broth was used during the year 1917 at the Bureau of Laboratories for the routine production of diphtheria toxin, with satisfactory results. In the early months of 1918, however, the potency of the toxin was irregular, and in the late spring several successive preparations of the broth gave too low a toxin for practical use. At this time we had just begun to use the Berna peptone for the production of tetanus toxin, and the idea occurred to us that this peptone might be satisfactory for obtaining a potent diphtheria toxin. Therefore a small amount of broth was made according to the method of Theobald Smith, but with the Berna peptone instead of Witte. The result of this test was very gratifying as a M L D of 1:350 was obtained. No comparative tests of Research No. 8 and Pasteur No. 8 were made at this time as I began a year's leave of absence. During this time all of the cultures in the different mediums were carried on by Miss Alice G. Mann whose cooperation is greatly appreciated. The 2 cultures, Pasteur No. 8 and Research No. 8 , were planted in Berna peptone broth and were transferred 3 times weekly.

On my return from France in 1919 the comparative tests in Berna peptone broth of the 2 cultures, Research No. 8 and Pasteur No. 8 were made, together with the second culture of No. 8 that had been obtained from the Pasteur Institute in the summer of 1919 and which is spoken of in the test as Pasteur 2 No. 8. The results are given in table 3 .

TABLE 3

Toxicities Produced in Benn Peptone Broth by Three Different Cultures of

B. Diphtheriag No, 8 after Cultivation in the Same Broth; Traksfers THREE TIMFS A WEeK

\begin{tabular}{|c|c|c|c|}
\hline Date of Test & $\begin{array}{c}\text { Research No. } 8 \\
\text { Cultivation Begun } \\
\text { May 4, 1918 }\end{array}$ & $\begin{array}{c}\text { Pasteur No. } 8 \\
\text { Cultivation Begun } \\
\text { May 4, } 1918\end{array}$ & $\begin{array}{c}\text { Pasteur } 2 \text { No. } 8 \\
\text { Cuitivation Begun } \\
\text { Aug. 19, } 1919\end{array}$ \\
\hline 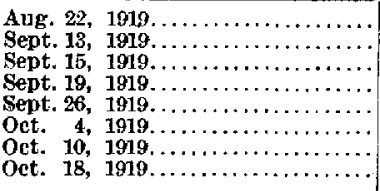 & $\begin{array}{l}\text { Below 1:100 } \\
\text { Below 1:100 } \\
\text { Below 1:100 } \\
\text { Below 1:100 } \\
\text { Below 1:100 } \\
\text { Below 1:100 } \\
\text { Below 1:100 }\end{array}$ & $\begin{array}{l}1: 100 \\
1: 250 \\
1: 500 \\
1: 500 \\
1: 100 \\
1: 100 \\
1: 250 \\
1: 150\end{array}$ & $\begin{array}{r}1: 100 \\
1: 250 \\
1: 500 \\
1: 400 \\
1: 100 \\
1: 100 \\
1: 250 \\
\text { Below } 1: 100\end{array}$ \\
\hline
\end{tabular}

Four of the 8 tests given in table 3 showed decidedly the greater toxigenic property of the two Pasteur cultures over that of Research No. 8. The toxicities of the other 4 tests were so uniformly low that less definite comparisons were possible. 
The toxin made from the Berna peptone broth was so inferior from October, 1919, through to the new year that efforts were made to discover whether there was a domestic peptone on the market which would be more satisfactory for diphtheria toxin production. A comparative test of Parke-Davis peptone and Berna peptone broths was made and inoculated with only Pasteur No. 8. The results were encouraging for the toxin made from Parke-Davis broth had a M LD of $1: 700$ in contrast to a M L of $1: 200$ obtained with Berna peptone broth. Accordingly, the 3 cultures were cultivated in broth made with Parke-Davis peptone. However, no comparative tests of the toxigenic powers were made until March, 1920. These and subsequent results are given in table 4 in which is also included three tests of the culture "American."

TABLE 4

Toxicities Produced in Parke, Dayis Peptone Broth hy Thine Drfaerent Cultures B. Diphtheriae No. 8 After Cultivation in the Same Broth; Transfers THREE TIMES A WEEK

\begin{tabular}{|c|c|c|c|c|}
\hline Date of Test & $\begin{array}{c}\text { Research No. } 8 \\
\text { Cultivation Begun } \\
\text { Jan. } 1,1920\end{array}$ & $\begin{array}{c}\text { Pasteur No. } 8 \\
\text { Cultivation Begun } \\
\text { Jan. } 1,1920\end{array}$ & $\begin{array}{c}\text { Pasteur 2 No. 8 } \\
\text { Cultivation Begun } \\
\text { Jan. 1, 1920 }\end{array}$ & "Americain"* \\
\hline $\begin{array}{l}\text { Mar. } 3,1920 \ldots \ldots \ldots \\
\text { Mar. } 12,1920 \ldots \ldots \ldots \\
\text { Nov. } 16,1920 \ldots \ldots \ldots \\
\text { Nov. } 26,1920 \ldots \ldots \ldots \\
\text { Jan. } 21,1921 \ldots \ldots \ldots \\
\text { April } 7,1921 \ldots \ldots \ldots\end{array}$ & $\begin{array}{l}1: 100 \\
1: 100 \\
1: 300 \\
1: 200 \\
1: 200 \\
1: 100\end{array}$ & $\begin{array}{l}1: 1000 \\
1: 800 \\
1: 900 \\
1: 1000 \\
1: 1000 \\
1: 1500\end{array}$ & $\begin{array}{c}\text { Not tested } \\
\text { Not tested } \\
\text { Not tested } \\
1: 700 \\
1: 300 \\
1: 700\end{array}$ & $\begin{array}{l}\text { Not tested } \\
\text { Not tested } \\
\text { Not tested } \\
1: 1000+ \\
1: 00+ \\
1: 800\end{array}$ \\
\hline
\end{tabular}

* This culture was obtained from Dr. Durand, Lyons, France, and was the B. diphtheriae No, 8 which had been sent him probably from the Pasteur Institute, Paris.

+ This eulture had been inoenlated into Parke-Davis peptone broth for geven generatjons before seeding of toxin flasks.

this had been in Parke, Davis broth for five generations before seeding of toxin flasks.

The marked differences in the toxigenic power of these strains were again in evidence. As far as was known, there was no explanation for the low toxicity of Pasteur's 2 No. 8 in the test made Jan. 21, 1921. This was $1: 300$ as against the M LD of $1: 1,000$ produced by Pasteur No. 8. In all the other comparative tests with the different peptones, the toxin made from Pasteur 2 No. 8 had corresponded very closely with the toxins made from Pasteur No. 8 with the exception of the experiment of Sept. 15, 1919, made in Witte peptone broth (table 2). Here Pasteur No. 8 produced a M L D of 1:400 as compared with a toxicity of $1: 250$ made from Pasteur 2 No. 8.

It is interesting to note that the "American" culture (table 4, Nov. 26, 1920) gave after only 7 generations in Parke-Davis peptone broth a toxin with as high a potency as the Pasteur No. 8 which had been cultivated 11 months in that medium. 
When it was eviclent that Research No. 8 produced consistently a very much lower toxin than either of the other strains, regardless of the length of cultivation in any particular broth, the thought occurred to us that it would be interesting to see what effect the different peptones may have had on the toxigenic power of Pasteur No. 8 after its cultivation in the different peptone broths. Accordingly, a preparation of Berna peptone broth was inoculated on July 23, 1920, with the Pasteur No. 8 culture which had been cultivated exclusively in Martin, Witte, Parke-

TABLE 5

Toxicities Produced in Berna Peptone Broth ey Fasteur No. 8 After Cultivation in Broths Made with Different Peptonf

\begin{tabular}{|c|c|c|c|}
\hline \multicolumn{2}{|c|}{ Transplanted Three Times Weekly } & \multirow{2}{*}{ Date of Test } & \multirow{2}{*}{ Toxicity } \\
\hline $\begin{array}{c}\text { First Transplant } \\
\text { of Series }\end{array}$ & $\begin{array}{c}\text { Cultivated in Broth } \\
\text { with }\end{array}$ & & \\
\hline $\begin{array}{l}\text { May } 4,1918 \\
\text { Dec. } 28,1916 \\
\text { Dec. } 28,1916 \\
\text { Jan. } 1,1920\end{array}$ & $\begin{array}{c}\text { Berna peptone broth } \\
\text { Witte peptone broth } \\
\text { Martin peptone broth } \\
\text { Parke-Davis peptone broth }\end{array}$ & $\begin{array}{l}\text { July } 23,1920 \\
\text { July } 23,1920 \\
\text { July } 23,1920 \\
\text { July } 23,1920\end{array}$ & $\begin{array}{c}1: 500 \\
\text { Below } 1: 100 \\
1: 450 \\
1: 450\end{array}$ \\
\hline
\end{tabular}

Davis and Berna peptone broths. The day before the test was started, seed cultures in Berna peptone broth were planted from these cultures, as fairly large amounts of the seed cultures were used to inoculate the toxin flasks and we wished to obviate carrying over any of the other peptone broths into the Berna broth. The results of this test, together with the dates of first cultivation in the different broths, are given in table 5 .

TABLE 6

Toxicities Produced in Witte Peptone Broth by Pasteur No. 8 Afrer Cultivation in Broths Mane, with Different Peptones

\begin{tabular}{|c|c|c|c|}
\hline \multicolumn{2}{|c|}{ Transplanted Three Times Weekly } & \multirow{2}{*}{ Date of Test } & \multirow{2}{*}{ Toxicity } \\
\hline $\begin{array}{c}\text { First Transplant } \\
\text { of Series }\end{array}$ & $\begin{array}{l}\text { Cultivated in Broth } \\
\text { with }\end{array}$ & & \\
\hline $\begin{array}{l}\text { Dec. } 28,1916 \\
\text { Dec. } 28,1916 \\
\text { May } 4,1918\end{array}$ & $\begin{array}{l}\text { Witte peptone broth } \\
\text { Martin peptone broth } \\
\text { Berna peptone broth }\end{array}$ & $\begin{array}{l}\text { Dee. } 9,1920 \\
\text { Dec. } 9,1920 \\
\text { Dee. } 9,1920\end{array}$ & $\begin{array}{l}1: 150 \\
1: 300 \\
1: 500\end{array}$ \\
\hline
\end{tabular}

The results of the foregoing test show that the cultures of Pasteur No. 8, which had been cultivated exclusively in Berna, Martin and Parke-Davis peptone broths, gave satisfactory toxins. The culture, however, which had been transferred in Witte broth since Dec. 28, 1916, gave a potency of below $1: 100$.

Another test was made with these same cultures which had been cultivated in broths made with Witte, Berna and Martin peptone, but 
instead of the Berna peptone broth, Witte peptone broth was used. As in the former test, the seed cultures were planted in Witte peptone broth before the inoculation in the Witte toxin broth.

Here again the culture which had been in Witte broth gave the lowest toxicity. This test was repeated 9 months later, on April 22, 1921 (table 7).

TABLE 7

Toxicities Produced in Witte Peptone Brote by Pasteur No. 8 After Cultrvation in Broths Made with Different Peptones

\begin{tabular}{|c|c|c|c|}
\hline \multicolumn{2}{|c|}{ Transplanted Three Times Weekly } & \multirow{2}{*}{ Date of Test } & \multirow{2}{*}{ Toxicity } \\
\hline $\begin{array}{c}\text { First Trunsplant } \\
\text { of Series }\end{array}$ & $\begin{array}{l}\text { Cultivated in Broth } \\
\text { with }\end{array}$ & & \\
\hline $\begin{array}{l}\text { May } 4,1918 \\
\text { Dee. } 28,1916 \\
\text { Dec. } 28,1916 \\
\text { Jan. } 1,1920\end{array}$ & $\begin{array}{l}\text { Berna peptone broth } \\
\text { Witte peptone broth } \\
\text { Martin peptone broth } \\
\text { Parke-Davis peptone broth }\end{array}$ & $\begin{array}{l}\text { April 22, } 1921 \\
\text { April 22, } 1921 \\
\text { April 22, } 1921 \\
\text { April 22, } 1921\end{array}$ & $\begin{array}{c}\text { 1:800 } \\
\text { Below 1:100 } \\
1: 700 \\
1: 700\end{array}$ \\
\hline
\end{tabular}

It will be seen that these results confirm the former test in the Witte peptone broth and also that in the Berna broth, in that the culture of Pasteur No. 8 which had been cultivated in the Witte broth gave the lowest toxicity.

Attempts will be made to confirm the results reported in this paper: (1) By subcultivating in Witte broth the culture Pasteur No. 8 which has been propagated continuously in Parke-Davis peptone broth since January, 1920, and which has given regularly a potent toxin in this medium; and by comparing these two cultures from time to time in order to determine whether the toxigenic powers of the culture in Witte broth has been adversely affected while the culture kept in Parke-Davis peptone broth retains its ability to produce strong toxin.

(2) By subcultivating Pasteur -No. 8, which has apparently lost its toxigenic power by cultivation in Witte broth, in Parke-Davis peptone broth to determine whether this culture after varying lengths of time in Parke-Davis broth may not regain its power to produce a potent toxin.

(3) By further cultivation of Pasteur 2 No. 8 in Witte broth to determine whether this culture will lose its toxigenic power in Witte peptone broth as Research No. 8 and Pasteur No. 8 have apparently done.

\section{SUMMARY}

The culture of Research No. 8 which has been propagated exclusively in Witte broth since 1895 at the Bureau of Laboratories has apparently lost its power to produce a potent toxin in any of the broths tested. 
The Pasteur cultures of No. 8 which were planted in Witte broth Dec. 28, 1916, has also apparently lost its ability to produce a potent toxin in both Witte and Berna peptone broths. The same culture kept in Berna, Martin and Parke-Davis peptone broth produces strong toxins in both the Berna and Witte broths.

The cultures of Research No. 8 which have been carried on in Berna, Martin and Parke-Davis peptone broths have not as yet recovered their powers to produce a potent toxin in any of the broths tested.

The toxigenic property of Pasteur 2 No. 8 culture has not as yet been affected deleteriously by the 2 years' cultivation (1919-1921) in Witte peptone broth.

\section{CONCLUSIONS}

It would seem in view of the foregoing results :

That Witte peptone broth had an inhibitory or destructive influence on the toxigenic powers of both Research No. 8 and Pasteur No. 8 cultures.

That Pasteur 2 No. 8 may be similarly affected after a still longer cultivation in Witte broth.

That the different preparations of Witte peptone received in this country just prior to 1914 may be responsible for this deleterious effect on the cultures. The fact, that culture Research No. 8 from the time of its isolation in 1895 to $1912-1913$ had been cultivated in Witte peptone broth without any signs of the lowering of its toxigenic property, as shown by the production of a potent toxin, tends to confirm this conclusion.

That it is possible that the different preparations of any peptone may vary in their effects on the toxigenic property of $B$. diphtheriae No. 8.

That the continuous cultivation of a culture of B. diphtheriae No. 8 in the same broth as that used for the toxin production is apparently not necessary for obtaining a potent toxin, is shown by the "American" strain of No. 8, which after only 7 generations in Parke-Davis broth gave as potent a toxin in that medium as Pasteur No. 8 which had been cultivated for 11 months in Parke-Davis broth. 